\title{
Postpartum mood disorders - A practitioner's guide to
}

\section{diagnosis and treatment}

Karien Botha, MBChB, MMed (Psych)

Piet Oosthuizen, MBChB, MMed (Psych)

Department of Psychiatry, Univer sity of

St ellenbosch

M ood disorders in the postpartum period are now recognised to be a major problem, affecting $10-22 \%$ of women..$^{1.3}$ A spectrum of mood disorders in the postpartum period is recognised, viz. postpartum blues, postpartum dep ression, and postpartum psychosis. $^{1,2,4}$

The differentiation between postpartum blues and depression can be difficult owing to an overlap of symptoms, often leading to underrecognition of the former. ${ }^{1,2}$

\section{Post part um blues}

The 'blues' is a very common entity in the postpartum period, affecting $50-85 \%$ of women. ${ }^{2}$ A significant percentage $(20 \%)^{2}$ of women with postpartum blues go on to develop postpartum depression (Table I).

The treatment of postpartum blues requires education and ongoing support of the patient, with continued evaluation of those at risk of developing postpartum depression. ${ }^{3}$

\section{Post partum depression}

The diagnostic criteria used for postpartum depression are similar to the Diagnostic and Statistical M anual (DSM -IV) criteria (Appendix A) for major depressive episode, with a modifier applying to the postpartum period (onset of episode within 4 weeks postpartum). ${ }^{3,5}$

The severity of symptoms and deterioration in social and/ or occupational functioning can be used to distinguish between
Table I. Comparison between postpart um blues and postpartum depression

\begin{tabular}{|c|c|}
\hline Postpart um blues ${ }^{1-3,9}$ & Postpartum depression ${ }^{5,9}$ \\
\hline $\begin{array}{l}\text { Symptoms up to } 10 \text { days after } \\
\text { delivery (should clear up } \\
\text { after this period) }\end{array}$ & $\begin{array}{l}\text { Symptoms within } 4 \text { weeks } \\
\text { of delivery, continuous } \\
\text { 2-week period }\end{array}$ \\
\hline $\begin{array}{l}\text { Symptoms } \\
\text { Mood lability } \\
\text { Depression } \\
\text { Imitability } \\
\text { Tearfulness } \\
\text { Anxiety } \\
\text { Sleep disturbance } \\
\text { Appetite disturbance }\end{array}$ & $\begin{array}{l}\text { Symptoms (5 or more of } \\
\text { following): } \\
\text { Depressed mood } \\
\text { Diminished interest or } \\
\text { pleasure in } \pm \text { all } \\
\text { activities } \\
\text { Weight loss or weight } \\
\text { gain } \\
\text { Insomnia orhypersomnia } \\
\text { Psychomotoragitation } \\
\text { or reta rda tion } \\
\text { Fatigue orloss of energy } \\
\text { Feelingsof worthlessness } \\
\text { orexcessive or inappro- } \\
\text { priate guilt } \\
\text { Diminished concentra- } \\
\text { tion or indec isiveness } \\
\text { Recurent thoughtsof } \\
\text { death orsuicidal ideation }\end{array}$ \\
\hline $\begin{array}{l}\text { Symptoms subside within } \\
10 \text { days of delivery with } \\
\text { only supportive intervention }\end{array}$ & $\begin{array}{l}\text { Symptoms persist for } \\
\text { longer than 2-week } \\
\text { period, affects } \\
\text { general functioning } \\
\text { and needs medical } \\
\text { treatment }\end{array}$ \\
\hline
\end{tabular}

postpartum blues and depression (Table I).

\section{Risk fact ors}

Id entified risk factors, which may increase the likelihood of post- 
Table II. Risk factors f $^{2,3,6-9}$

Personal psychiatric history of mood disorder

Fa mily history of depression

Low levels of social and spouse support

Recent adverse life events

Unwanted pregnancy

Underlying thyroid disease ( $5 \%$ of postpartum women have transient hypothyroidism) ${ }^{9}$

Adolescent mothers

Manital conflict

Child care-related stressors (feeding, sleep problems, infant's health, and temperamentally difficult infants)

partum depression, a re listed in Table

\section{Screening scales}

It may be difficult for the clinician to decide whether symptoms of depression are due to a period of adjustment after having a baby, or the result of a fully fledged mood disorder. First-time mothers may not recognise that they are depressed - societal pressure may cause reluctance to admit to a problem, owing to shame and fear. Furthermore, new mothers often do not know who to turn to for help. ${ }^{9}$ It is therefore important to identify women at risk and to monitor them closely a fter delivery.

The Edinburgh Postnatal Depression Scale (EPDS) is currently the instrument of choice for identifying postpartum mood disorders, as it was specifically designed for this purpose. ${ }^{9}$ This scale is an inexpensive, convenient and accurate self-rating screening tool for postpartum depression ${ }^{10}$ with high sensitivity $(100 \%)$ and specificity $(95.5 \%)$ in detecting major depression. ${ }^{9}$

\section{Basi c pr inciples of the Edinbur gh Postnatal} Depr essi on Scal $e^{9-12}$

The EPDS is a self-report scale measuring symptoms experienced in the previous week ( 7 days). There are 10 statements related to depressive symptoms, each statement rated from 0 to $3(0=$ no symptoms, 3 = severe symptoms), with a possible total score of $0-30$. A score of 10 or less identifies women at risk, while a score of 13 or more indicates that the woman is probably experiencing postpartum depression.

Edi nbur gh postnatal depr essi on scal $\mathrm{e}^{10,13}$
The EPDS is ideally administered at 5-8, $10-14$ and $20-26$ w eeks postpartum. ${ }^{13}$

W omen a re asked to answ er all 10 questions, underlining the answ er that comes closest to how they have felt over the past 7 days, i.e. not just on that day (Appendix B).

\section{Consequences of non-treat ment of post partum depression}

Inadequate treatment of postpartum depression increases the risk of sequelae of untreated mood disorders, i.e. a pattern of chronic depression and recurrent, refractory disease. ${ }^{1}$

$\mathrm{N}$ on-treatment increases the incidence of postpartum psychotic depression, suicide and infanticide. A higher rate of violent suicide is present among teenage and unmarried mothers. ${ }^{3,4}$

Depressed mothers display a negative interaction style with their infants and the infants in turn display lower activity levels, tending to be more irritable and to show less positive facial expressions. ${ }^{11}$

Postpartum depressed mothers show raised levels of hostility to wards their infants and fail to acknow ledge infant a uto nomy. A pattern of a voidant child behaviour may be established. By age 5 years, many of these children have developed patterns in which the sense of self agency is reduced and self negation is increased. They also tend to fail to respond to others' social initiatives. ${ }^{14}$

An increase in hyperactive behaviour, especially in boys, has been found to be prevalent in children of mothers with postpartum depression. ${ }^{15}$

\section{Postpartum psychosis}

Postpartum psychosis occurs in $0.2 \%$ of childbearing women. The onset is normally within 1 month of delivery and is manic in nature. Early warning signs are inability to sleep, agitation, expansive or irritable mood and avoidance of the infant Delusions or hallucinations often involve the infant, for example the mother may experience auditory hallucinations, telling her to kill the infant Postpartum psychosis is a medical emergency as the mother may potentially harm herself or the infant. Most patients are hospitalised and treated with antipsychotics and mood stabilisers. 


\section{Treat ment options}

The approach to the treatment of postpartum depression is similar to the treatment of non-puerperal depression. The welfare of the mother, baby and other children should be a primary concern. Remedial social factors should be attended to. It is important to

involve the woman's partner in emotional and practical support ${ }^{16}$

\section{Pharmacotherapy}

Pharmacotherapy may be used alone or in combination with psychotherapy.

\section{Anti depr essant tr eatment}

Several studies have demonstrated the efficacy of antidep ressant medication in the treatment of major depression. Standard antidepressant doses were found to be effective and well tolerated.

Tricyclic antidepressants (TCAs) were prescribed most frequently in the past, although selective serotonin re-uptake inhibitors (SSRIs) are probably better tolerated and may therefore be the first-line trea tment of choice. Postpartum depression is often associated with anxiety and agitation. Benzodiazepine treatment should be used only as an adjuvant to antidepressant medication for a short period of time.

The initial dose of antidepressant medication (Table III) should be maintained for 2 weeks, before adjustment is considered. Most patients show improvement in symptoms within 2 - 4 weeks of starting medication. Clinical improvement should be obtained within 6 - 8 weeks of commencing antidep ressant trea tment.

Patients who are decompensating despite high doses of antidepressant medication or who are not responding adequately should be referred to a psychiatrist.

The optimal duration of treatment should be at least $9-12$ months (first episode).

W omen with postpartum depression often experience disturbing, aggressive obsessional thoughts towards the infant and may respond preferentially to SSRI treatment ${ }^{18}$

\section{Hor monal ther apy}

$\mathrm{N} 0$ systematic data support the use of progesterone in the treatment of postpartum depression. 0 estrog en therapy (either alone or in combination with antidep ressant therapy) has putative efficacy in the treatment of postpartum depression, but further research is needed to confirm this. 1

\section{Prescribing ant idepressant s during breast -f eeding}

All antidepressants a re secreted in breast-milk, but the (limited) a vailable data suggest that plasma concentrations of TC As and SSRIs in breastfed infants are rarely detectable on standard assays. ${ }^{9,16}$ The evidence does not seem to warrant recommendation that the mother stops breast-feeding while taking TCAs or SSRIs in usual doses; how ever, minimum effective doses are recommended. ${ }^{16}$

The risk-benefit ratio of antidepressant therapy while breast-feeding should always be discussed with the mother and her partner and written, informed consent obtained. Risk factors should be taken into account, especially with a past history of major depression. Risk factors in the infant should also be evaluated, such as premature birth or any dysfunction that may impair drug metabolism and clearance. If a decision is made to continue breastfeeding while on antidepressants, mother and baby should be monitored closely for possible unwanted effects. ${ }^{16}$

'The mother may feed the infant with previously expressed milk for the first few hours following drug ingestion. ${ }^{17}$

Lithium should be used with caution during breast-feeding. $\mathrm{N} 0$ controlled studies have been done, but infant serum lithium levels may be elevated, causing possible cyanosis, hypotonia and electrocardiogram changes. ${ }^{17}$

\section{Benzodiazepines with a long half-ife should be avoided} because they may accumulate in the blood and can result in sedation and poor feeding of the infant. ${ }^{17}$

\section{Psychotherapy}

Psychotherapy forms an integral part of the treatment of all mood disorders. It may be considered as single treatment modality for women who are reluctant to take antidepressant medication during breastfeeding, especially for those with milder forms of postpartum depression. ${ }^{1,9}$

Interpersonal therapy may be particularly useful, as it focuses on the patient's interpersonal relationships and changing roles. ${ }^{1,9}$ 
Table III. Dosage, half-life and side-effects of antidepressant s commonly used to treat major depression ${ }^{9}$

\begin{tabular}{|c|c|c|c|}
\hline & $\begin{array}{l}\text { Starting } \\
\text { dose }\end{array}$ & $\begin{array}{l}\text { Usual daily } \\
\text { dose }\end{array}$ & Possible side-effects \\
\hline \multicolumn{4}{|l|}{ Tric yc lic a ntidepressants (mg) } \\
\hline Amitriptyline (Tryptanol) & $25-75$ & $100-300$ & \multirow{4}{*}{$\begin{array}{l}\text { Constipation, sedation, } \\
\text { weight ga in, orthostatic } \\
\text { hypotension, blurred } \\
\text { vision, dry mouth }\end{array}$} \\
\hline Imipramine (Tofranil) & & & \\
\hline Clomipramine (Anafra nil) & & & \\
\hline Lofepramine (Emdalen) & 70 & $140-210$ & \\
\hline \multicolumn{4}{|l|}{ SSRI (mg) } \\
\hline Fluoxetine (Prozac) & 20 & $20-40$ & \multirow{4}{*}{$\begin{array}{l}\text { Headache, nausea, } \\
\text { diamhoea, nervousness, } \\
\text { sedation, insomnia, } \\
\text { tremor }\end{array}$} \\
\hline Sertraline (Zoloft)* & 50 & $50-150$ & \\
\hline Paroxetine (Aropax)* & 20 & $20-40$ & \\
\hline Fluvoxamine (Luvox)* & 50 & $100-300$ & \\
\hline \multicolumn{4}{|l|}{ Atypic al a ntidepressa nts (mg) } \\
\hline Venlafaxine (Efexor) & 75 & $75-225$ & $\begin{array}{l}\text { Insomnia, a norexia, } \\
\text { nervousness, sustained } \\
\text { hypertension }\end{array}$ \\
\hline Nefazodone & 200 & $300-600$ & $\begin{array}{l}\text { Orthostatic hypotension, } \\
\text { somnolence, dry mouth, } \\
\text { na usea }\end{array}$ \\
\hline Mirtaza pine & 15 & $15-45$ & $\begin{array}{l}\text { Somnolence, na usea, } \\
\text { weight gain, raised } \\
\text { cholesterol and triglyc eride } \\
\text { level, a gra nulocytosis }\end{array}$ \\
\hline
\end{tabular}

A number of studies have found cognitive behaviour therapy

(C BT) to be as effective as fluoxetine in the treatment of postpar-

tum depression. 1.9

\section{Prevention of postpartum depression and relapse}

G ynaecologists, general practitioners and antenatal clinics play an important role in raising awareness of mood disorders in the postpartum period.

Education of patients and their families regarding the signs and symp toms of postpartum depression (pamphlets, posters, video presentations), ${ }^{9}$ should be instituted.

Preventive treatment with antidepressant medication should be considered. It has been found that women who receive preventive antidepressant therapy have a significantly lower rate of recurrence of postpartum major depression. ${ }^{18}$

There is no advantage to starting treatment prenatally. To a void fetal exposure it is suggested that antidep ressant treatment should be started directly after parturition. ${ }^{18}$
The prophylactic use of homones has been suggested and in one a necdotal series oestrogen plus testosterone (for lactation suppression) reduced the risk of major depression in the postpartum period..$^{18}$

\section{Support groups in South Africa}

Support groups in South Africa include the Postnatal Depression Support G roup, Tel: 082-8820072; and the Anxiety and Depression Support G roup (national), Tel: 011-7831474/6, $011-8841797,0800119283$ (tollfree). Also see the following w ebsite: www .iup.edu/ an/ postpartum/

\section{References}

1. N onacs R, C ohen LS. Postpartum mood disorders: Diagnosis and treatment guidelines. J C lin Psychiatry 1998; 59: suppl 2, 34-38.

2. Lewellyn $A M$, Zachary $N S, N$ emeroff $C B$. Depression during pregnancy and the puerperium. J C lin Psychiatry 1997; 58: suppl 15, 22,28,29.

3. Pa riser SF, N asrallah HA, G ardner PK. Postpartum mood disorders: C linical perspectives. J W omens Health 1997; 6: 422-424.

4. Romito P. Postpartum depression and the experience of motherhood. Acta 0 bstet Gynecol Scand 1990; 69: suppl 154, 7-19, 154 .

5. Kaplan HI, Sadock BJ, G rebb JA. Kaplan and Sadock's Synopsis of Psychia try. 7 th ed. Baltimore: W illiams and W ilkins, 1994: 530

6. Stowe $\mathrm{N} Z, \mathrm{~N}$ emeroff $\mathrm{CB}$. W omen at risk for post-partum onset major depression. A m J O bstet G ynecol 1995; 173: 640 .

7. A merican Academy of Family Physicians. Postpartum depression and the 'Baby Blues', 1999: 1 . 
8. Righetti-Veltema $M, C$ onne-Pierré $E$, Bousquet $A, M$ anzano J. Risk factors and predic tive signs of postpartum depression. J Affect Disord 49, 1998; 49: 167-180.

9. Epperson CN . Post-partum major depression: Detection and treatment. Am Fam Physician 199 9; 59: 2247-2252.

10. Evins $G G$, Theofrastous JP, $G$ alvin SL. Postpartum depression: A comparison of screening and routine clinical evaluation. Am J 0 bstet $G$ ynecol 2000 ; 182: 1080-1082.

11. Beck C T, G able RK. Postpartum Depression Screening Scale: Development and psychometric testing. N urs Res 2000; 29: $272-273$.

12. Schaper AM, Rooney BL, Kay N R, Silva PD. Use of the Edinburgh Post Natal Depression Scale to identify postpartum depression in a clinical setting. J Reprod Med 1994; 39: 621

13. Cox J, Holden JM. Use and misuse of the Edinburgh Postnata I Depression Scale. In: C ox JL, Holden JM, eds. Perinatal Psychia try. London: G askell, 1996: 125-144.

14. Murray $L$ Sincla ir $D, C$ ooper $P$, Ducourna $P$, Turner $P$. The socioemotional develop ment of 5 -year-old children of postnatally depressed mothers. I C hild Psychol Psychiatry 1999; 40: 1268-1269.

15. Sinclair $D, M$ urray $L$. Effects of postnatal depression on children's adjustment to school. Br J Psychiatry 1998; 172: 61 .

16. The management of postnatal depression. Drug and Therapeutics Bulletin 2000; 38: 35 .

17. Austin M P V V M itchell PB. Use of psychotropic medications in breastfeeding women: acute and prophylactic treatment. A ust N Z J Psychiatry 1998; 32: 782 783

18. W isner KL, Peindl KS, G igliotti T, Hanusa, BH. O bsessions and compulsions in women with postpartum depression. J C lin Psychiatry 1999; 60: 176-180.

19. Ha milton JA. The identity of postpartum psychosis. In: Brockington IF, Kumar R, eds. Motherhood and Mentalliness, Iondon: Academic Press, 1982.

\section{Appendix A. DSM-IV Criteria for Major Depressive Episode}

A. Five (or more) of the following symptoms have been present during the same 2 -week period and represent a change from previous functioning. At least one of the symptoms is either:

(i) depressed mood; or (ii) loss of interest or pleasure.

(1) Depressed mood most of the day, nearly every day, as indicated by either subjective report (e.g. feels sad or empty) or observation made by others.

(2) M arkedly diminished interest or pleasure in all, or almost all, activities, most of the day, nearly every day.

(3) Significant weight loss or weight gain when not dieting (e.g. more than $5 \%$ of body weight in a month) or decrease or increase in appetite nearly every day.

(4) Insomnia or hypersomnia nearly every day.

(5) Psychomotor agitation or retardation nearly every day (observable by others, not merely subjective feelings of restlessness or being slowed down).

(6) Fatigue or loss of energy nearly every day.

(7) Feelings of worthlessness or excessive or inapprop ria te guilt (which may be delusional) nearly every day.

(8) Diminished a bility to think or concentrate, or indecisiveness nearly every day (either by subjective account or as observed by others).

(9) Recurrent thoughts of death (not just fear of dying), recurrent suicidal ideation without a specific plan, or a suicide attempt or a specific plan for committing suicide.

B. The symptoms do not meet criteria for a mixed episode.

$C$. The symptoms cause clinically significant distress or impairment in social, occupational or other important a reas of functioning.

D. The symptoms are not due to the direct physiological effects of a substance (e.g. a drug of abuse, a medication) or a general medical condition (e.g. hypothyroidism).

E. Bereavement, i.e. after the loss of a loved one: the symptoms persist for longer than 2 months or are characterised by marked functional impairment, morbid preoccupation with worthlessness, suicidal ideation, psychotic symptoms or psychomotor retardation.

\section{Appendix B. Edinburgh Post nat al Depression Scale*}

In the past 7 days: Score

1. I have been able to laugh and see the funny side of things:

(a) As much as I always do 0

(b) N ot quite so much now 1

(c) Definitely not so much now 2

(d) N ot at all

2. I have looked forward to enjoyment of things:

(a) As much as I ever did 0

(b) Rather less than I used to 1

(c) Definitely less than I used to 2

(d) Hardly at all 3

3. I have blamed myself unnecessarily when things went wrong:

(a) Yes, most of the time 3

(b) Yes, some of the time 2

(c) $\mathrm{N}$ ot very often 1

(d) $\mathrm{N} 0$, never $\quad 0$

4. I have felt worried and anxious for no very good reason:

(a) N O, not at all 0

(b) Hardly ever 1

(c) Yes, sometimes 2

(d) Yes, very often 3 
5. I have felt scared or panicky for no very good reason:

(a) Yes, quite a lot 3

(b) Yes, sometimes 2

(c) $\mathrm{N} 0$, not much 1

(d) N o, not at all 0

6. Things have been getting on top of me:

(a) Yes, most of the time I haven't been able to cope atall

(b) Yes, sometimes I haven't been coping as well as usual

2

(c) N 0, most of the time I have coped quite well 1

(d) N 0, I have been coping as well as ever 0

7. I have been so unhappy that I have had difficulty sleeping:

(a) Yes, most of the time

3

(b) Yes, sometimes

(c) $\mathrm{N}$ ot very often (d) $\mathrm{N} 0$, not at all

0

8. I have felt sad or miserable:

(a) Yes, most of the time 3

(b) Yes, quite often 2

(c) $\mathrm{N}$ ot very often 1

(d) N 0, notatall 0

9. I have been so unhappy that I have been crying:

(a) Yes, most of the time 3

(b) Yes, quite often 2

(c) 0 nly occasionally 1

(d) $\mathrm{N} 0$, never 0

10. The thought of harming myself has occured to me:
(a) Yes, quite often
(b) Sometimes
2
(c) Hardly ever
1
(d) $\mathrm{N}$ ever
0

3 